\title{
Massilia aurea sp. nov., isolated from drinking water
}

\author{
Virginia Gallego, Cristina Sánchez-Porro, Maria Teresa García \\ and Antonio Ventosa
}

Correspondence

Antonio Ventosa

ventosa@us.es

\author{
Department of Microbiology and Parasitology, Faculty of Pharmacy, University of Sevilla, 41012 \\ Sevilla, Spain
}

\begin{abstract}
A Gram-negative, motile, rod-shaped organism, strain $\mathrm{AP}_{13}{ }^{\top}$, able to produce yellow-pigmented colonies, was isolated from the drinking water distribution system of Seville (Spain) and was characterized by using a polyphasic taxonomic approach. In 16S rRNA gene sequence comparisons, strain AP13 ${ }^{\top}$ exhibited $96 \cdot 9-95 \cdot 6 \%$ similarity with respect to the five recognized species of the genus Massilia. The DNA G $+C$ content of strain $A P 13^{\top}$ was $66 \cdot 0$ mol\%, a value that supports the affiliation of strain $\mathrm{AP} 3^{\top}$ to the genus Massilia. DNA-DNA hybridization data and phenotypic properties confirmed that strain $A P 13^{\top}$ represents a novel species of the genus Massilia, for which the name Massilia aurea sp. nov. is proposed. The type strain is AP13 ${ }^{\top}(=C E C T$ $7142^{\top}=$ CCM $7363^{\top}=$ DSM $18055^{\top}=$ JCM $\left.13879^{\top}\right)$.
\end{abstract}

The genus Massilia belongs to the family Oxalobacteraceae (Betaproteobacteria) and, to date, comprises five species, Massilia timonae (La Scola et al., 1998), Massilia dura, Massilia albidiflava, Massilia plicata and Massilia lutea (Zhang et al., 2006), with M. timonae as the type species. The genus Massilia was described by La Scola et al. (1998) on the basis of a single isolate from the blood of an immunocompromised patient. Moreover, strains related to $M$. timonae have been isolated from human patients (Lindquist et al., 2003). However, the isolation from soil samples of phenanthrene-degrading (Bodour et al., 2003), proteaseproducing (Wery et al., 2003) and $N$-acyl homoserine lactone-producing (d'Angelo-Picard et al., 2005) strains related to the genus Massilia, as well as the recently described four novel species of the genus Massilia isolated from different soil samples from south-east China (Zhang et al., 2006), showed that species of this genus can be isolated from environmental samples.

To monitor the quality of the drinking water of Seville (Spain), we carried out several microbiological studies from April 2003 to January 2004. Samples (25 1) of drinking water were concentrated by using a tangential flow filtration system (Filtron; Pall), plated on plate count agar (PCA; Difco) and incubated at $28^{\circ} \mathrm{C}$ for 7 days. Colonies with different morphologies were subsequently plated, using the same isolation medium, in order to obtain pure cultures. Strain $\mathrm{AP} 13^{\mathrm{T}}$ was isolated during the sampling campaign of April 2003 and was studied phylogenetically, phenotypically and genotypically. On the basis of the results of these studies,

The GenBank/EMBL/DDBJ accession number for the $16 \mathrm{~S}$ rRNA gene sequence of strain $\mathrm{AP}^{\mathrm{T}} 3^{\mathrm{T}}$ is $\mathrm{AM} 231588$. we propose that strain $\mathrm{AP} 13^{\mathrm{T}}$ represents a novel species of the genus Massilia.

Chromosomal DNA was isolated and purified according to the method described by Marmur (1961). The 16S rRNA gene was amplified using the universal primers 16F27 and 16R1488, as described by Mellado et al. (1995). The almostcomplete nucleotide sequence was determined by NBTNewbiotechnic (Seville, Spain) using an automated DNA sequencer (model 3100; Applied Biosystems). A sequence analysis was subsequently conducted by using the ARB program package (Ludwig et al., 2004). According to the recommendations of Ludwig et al. (1998), alternative treeing methods (maximum parsimony, distance matrix and maximum likelihood) were carried out. A comparison using 16S rRNA gene sequences from databases revealed that the sequence of strain $\mathrm{AP} 13^{\mathrm{T}}$ displays the highest levels of similarity with those from Massilia species. The sequence similarities with respect to Massilia species were $\leqslant 96.9 \%$, M. timonae being the most closely related species. The phylogenetic tree obtained with the maximum-parsimony method placed strain $\mathrm{AP} 13^{\mathrm{T}}$ within the branch constituted by Massilia species (Fig. 1). These results were consistent with those obtained with other algorithms. According to the phylogenetic data, the novel isolate belongs to the genus Massilia, but, as it shows relatively low similarity with other species in the genus, strain $\mathrm{AP}^{\mathrm{T}}{ }^{\mathrm{T}}$ could be considered a novel species (Stackebrandt \& Goebel, 1994).

The $\mathrm{G}+\mathrm{C}$ content of the genomic DNA was determined from the mid-point value $\left(T_{\mathrm{m}}\right)$ of the thermal denaturation profile (Marmur \& Doty, 1962), using the equation of Owen \& Hill (1979), as previously described in detail by Ventosa et al. (1999). The DNA G+C content was found to be 


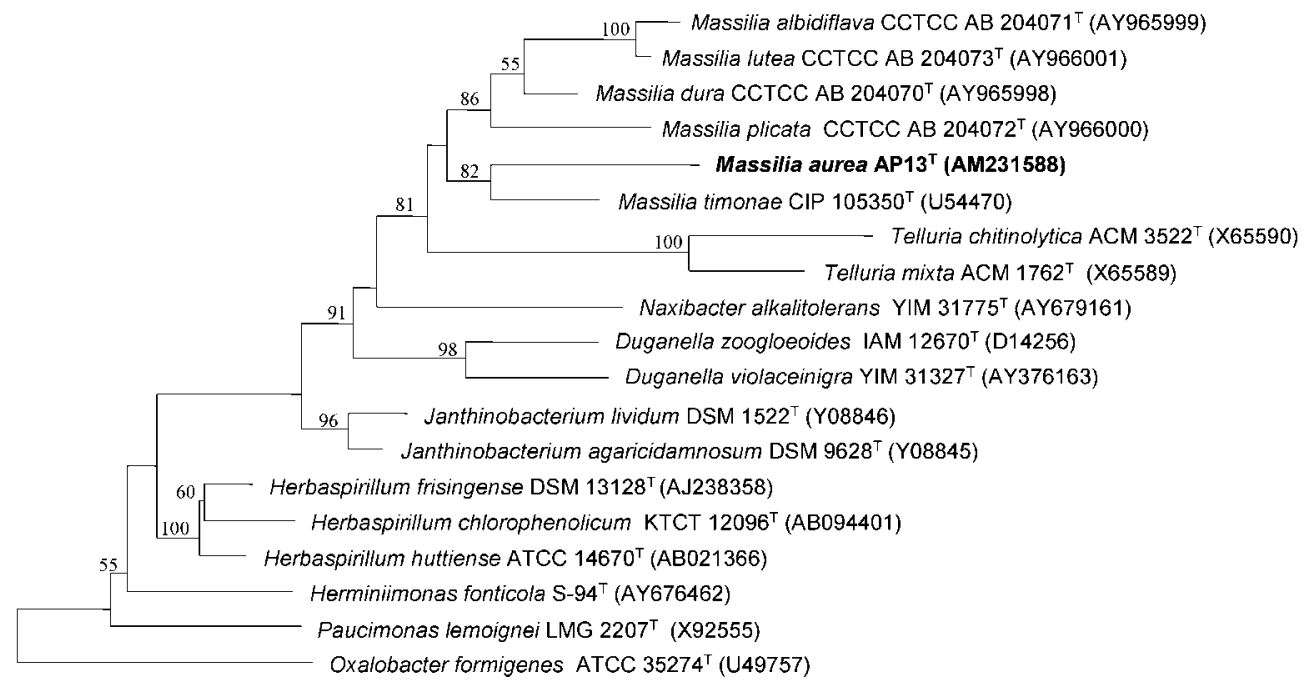

0.01

Fig. 1. Maximum-parsimony phylogenetic tree showing the relationships of strain $A P 13^{\top}$, species belonging to the genus Massilia and other related members of the Betaproteobacteria. Bootstrap values $>50 \%$ are indicated at the branch points. Bar, $1 \%$ sequence divergence.

$66.0 \mathrm{~mol} \%$, which is within the range for the genus Massilia (La Scola et al., 1998; Zhang et al., 2006). DNA-DNA hybridization studies were performed using the competition procedure of the membrane method (Johnson, 1994), which was described in detail by Mormile et al. (1999). The hybridization temperature was $59^{\circ} \mathrm{C}$, which is within the limit of validity for the filter method (De Ley \& Tijtgat, 1970), and the degree of hybridization (\%) was calculated according to Johnson (1994). The experiments were carried out in triplicate. The level of DNA-DNA hybridization between strain $\mathrm{AP} 13^{\mathrm{T}}$ and M. timonae DSM $16850^{\mathrm{T}}$ was $13 \%$, confirming that strain $\mathrm{AP}^{2} 3^{\mathrm{T}}$ constitutes a novel species (Stackebrandt \& Goebel, 1994).

The shape and motility of the bacterial cells were observed under a phase-contrast microscope $($ at $\times 1000)$ from a $24 \mathrm{~h}$ liquid culture (nutrient broth). Growth at different temperatures $\left(4-40^{\circ} \mathrm{C}\right), \mathrm{pH}$ values $(\mathrm{pH} 4-9)$ and $\mathrm{NaCl}$ concentrations $(0-5 \% \mathrm{NaCl})$ was tested on PCA medium. The isolate was also tested for its ability to grow on nutrient agar medium, trypticase soy agar (TSA; Difco), R2A (Difco) and MacConkey agar (Scharlau). $\mathrm{H}_{2} \mathrm{~S}$ production was determined on Kligler iron agar (Difco). Oxidase activity was detected using a $1 \%$ solution of tetramethyl- $p$ phenylenediamine (Difco) (Kovács, 1956). Catalase activity was tested by picking a young colony and smearing it in a drop of $\mathrm{H}_{2} \mathrm{O}_{2}$. The methyl red and Voges-Proskauer reactions were tested on Clark-Lubs' medium (Scharlau). Indole production was determined with Kovács' reagent on $1 \%$ tryptone broth. A citrate test was performed on Simmons' citrate agar (Sigma). For the determination of acid production from different carbohydrates, a medium containing $0.5 \%$ peptone, $0.5 \% \mathrm{NaCl}$ and $0.001 \%$ phenol red was used (Cowan \& Steel, 1974). The reduction of nitrate and nitrite was tested on nitrate broth containing $0 \cdot 2 \% \mathrm{KNO}_{3}$ (Skerman, 1967). Urease activity was studied in Christensen's medium (Christensen, 1946). The hydrolysis of gelatin, starch and DNA was tested on the corresponding agar media (Scharlau) (Cowan \& Steel, 1974). Tween 80 hydrolysis was tested in PCA medium containing $1 \%$ Tween 80 and $0.02 \% \mathrm{CaCl}_{2}$ (Sierra, 1957). Casein hydrolysis was tested in PCA medium supplemented with $2 \%$ skim milk (Difco) (Cowan \& Steel, 1974).

Tests for carbon-source utilization, sugar fermentation and enzymes (qualitative) were carried out using API 20NE, API ID 32E and API ZYM kits (bioMérieux) inoculated according to the manufacturer's instructions and incubated at $28^{\circ} \mathrm{C}$. An API $50 \mathrm{CH}$ strip was inoculated as described by Kersters et al. (1984). Antibiotic susceptibility was determined according to the conventional Kirby-Bauer method (Bauer et al., 1966). The results of the phenotypic analysis are summarized in the species description. Several phenotypic characteristics that can be used to differentiate strain AP $13^{\mathrm{T}}$ from Massilia species are summarized in Table 1.

Fatty acid analysis and analysis of quinones were carried out by the Identification Service of the Deutsche Sammlung von Mikroorganismen und Zellkulturen (Braunschweig, Germany). Cells were cultured on TSA medium for $24 \mathrm{~h}$ at $\mathrm{pH} 7 \cdot 0$ and $28^{\circ} \mathrm{C}$ by using the methods described by Miller (1982) and Kämpfer \& Kroppenstedt (1996). The predominant fatty acids of strain $\mathrm{AP} 13^{\mathrm{T}}$ were $\mathrm{C}_{16: 1} \omega 7 c$ and $\mathrm{C}_{16: 0}$. The fatty acid profile of strain $\mathrm{AP} 13^{\mathrm{T}}$ is very similar to 
Table 1. Differential characteristics of strain $A P 13^{\top}$ and species of the genus Massilia

Taxa: 1, strain $\mathrm{AP}^{\mathrm{T}}{ }^{\mathrm{T}}$; 2, M. timonae; 3, M. dura; 4, M. albidiflava; 5, M. plicata; 6, M. lutea. Data for strain AP13 ${ }^{\mathrm{T}}$ and M. timonae DSM $16850^{\mathrm{T}}$ are from this study. Data for M. dura CCTCC AB 204070 ${ }^{\mathrm{T}}$, M. albidiflava CCTCC AB 204071 ${ }^{\mathrm{T}}$, M. plicata CCTCC AB $204072^{\mathrm{T}}$ and M. lutea CCTCC $\mathrm{AB} 204073^{\mathrm{T}}$ are from Zhang et al. (2006). +, Positive; -, negative; W, weak; ND, not determined. All strains show the following phenotypic characteristics: cells are motile, non-spore-forming rods; colonies are yellow-pigmented; catalase-positive and $\beta$-galactosidase-positive; negative for indole and $\mathrm{H}_{2} \mathrm{~S}$ production.

\begin{tabular}{|c|c|c|c|c|c|c|}
\hline Characteristic & 1 & 2 & 3 & 4 & 5 & 6 \\
\hline Optimum growth temp. $\left({ }^{\circ} \mathrm{C}\right)$ & 28 & 28 & $28-30$ & $28-30$ & $28-30$ & $28-30$ \\
\hline Optimum growth $\mathrm{pH}$ & $7 \cdot 0-8 \cdot 0$ & $\mathrm{ND}$ & $7 \cdot 0-7 \cdot 5$ & $7 \cdot 0-7 \cdot 5$ & $7 \cdot 0-7 \cdot 5$ & $7 \cdot 0-7 \cdot 5$ \\
\hline Oxidase & $\mathrm{W}$ & + & + & + & - & + \\
\hline Nitrate reduction & - & - & + & + & + & - \\
\hline Voges-Proskauer test & - & - & - & - & + & - \\
\hline Starch hydrolysis & + & + & - & + & + & + \\
\hline \multicolumn{7}{|l|}{ Enzyme activities } \\
\hline$\alpha$-Chymotrypsin & - & + & ND & ND & $\mathrm{ND}$ & ND \\
\hline$\alpha$-Mannosidase & - & + & ND & $\mathrm{ND}$ & $\mathrm{ND}$ & ND \\
\hline Lysine decarboxylase & - & - & - & + & - & - \\
\hline$\beta$-Glucuronidase & - & - & + & + & - & + \\
\hline$N$-Acetylglucosamidase & - & - & + & + & - & + \\
\hline Lipase & - & - & - & + & + & + \\
\hline Urease & - & - & + & + & + & - \\
\hline Habitat & Drinking water & Blood & Soil & Soil & Soil & Soil \\
\hline DNA G $+C$ content $(\mathrm{mol} \%)$ & $66 \cdot 0$ & $62-67$ & $65 \cdot 9$ & $65 \cdot 3$ & $65 \cdot 1$ & $63 \cdot 3$ \\
\hline
\end{tabular}

those of recently described Massilia species, with $\mathrm{C}_{16: 0}$ and $\mathrm{C}_{16: 1} \omega 7 c$ and/or iso- $\mathrm{C}_{15: 0} 2-\mathrm{OH}$ as the predominant fatty acids (Table 2). Like members of the genus Massilia, strain $\mathrm{AP} 13^{\mathrm{T}}$ contains ubiquinone $\mathrm{Q}-8$ as the major quinone.

On the basis of the phylogenetic, genotypic and phenotypic (and chemotaxonomic) data, we propose strain $\mathrm{AP}_{13}{ }^{\mathrm{T}}$ as a novel species within the genus Massilia with the name Massilia aurea sp. nov.

\section{Description of Massilia aurea sp. nov.}

Massilia aurea (au're.a. L. fem adj. aurea golden, referring to the yellowish pigment that the bacterium produces).

Cells are Gram-negative, straight rods $1 \cdot 0 \times 1 \cdot 6-3 \cdot 0 \mu \mathrm{m}$ in size that occur singly or in pairs (on PCA medium at $28^{\circ} \mathrm{C}$ after $48 \mathrm{~h}$ ). Cells are motile, non-spore-forming and strictly aerobic. Colonies are circular, translucent, yellow-pigmented and $0 \cdot 6-1 \cdot 0 \mathrm{~mm}$ in diameter on PCA agar after 2 days incubation. Good growth occurs on TSA, R2A and nutrient agar medium. Does not grow on MacConkey agar. Cells have a tendency to form pellicles on the surface of static liquid cultures. Does not grow in the presence of $2 \% \mathrm{NaCl}$. Growth occurs at $4-30^{\circ} \mathrm{C}$ (optimum temperature, $28^{\circ} \mathrm{C}$ ) and at $\mathrm{pH} 4 \cdot 0-9 \cdot 0$ (optimum $\mathrm{pH}, 6 \cdot 0-7 \cdot 0$ ). Catalasepositive. Weakly oxidase-positive. Urease-negative. Negative for indole production, hydrogen sulfide production and nitrate reduction, and in the methyl red and VogesProskauer tests. Glucose is not fermented. Simmons' citrate test is positive. Starch, gelatin, casein and DNA are hydrolysed but Tween 80 is not. Acid is not produced oxidatively from D-galactose, D-mannose, D-glucose, Dfructose, D-maltose, glycerol, D-mannitol, D-trehalose, Dxylose or lactose. Alkaline and acid phosphatase, esterase (C4), esterase lipase (C8), leucine arylamidase, valine arylamidase, naphthol-AS-BI-phosphohydrolase, $\beta$-galactosidase and $\alpha$-glucosidase are present. Negative for arginine dihydrolase, lysine decarboxylase, ornithine decarboxylase, tryptophan deaminase, lipase (C14), cysteine arylamidase, trypsin, $\alpha$-chymotrypsin, $\alpha$-galactosidase, $\beta$-glucuronidase, $N$-acetyl- $\beta$-glucosaminidase, $\alpha$-mannosidase and $\alpha$-fucosidase. Utilizes D-xylose, D-glucose, D-fructose, D-mannose, L-rhamnose, $N$-acetylglucosamine, amygdalin, aesculin, Dcellobiose, D-maltose, starch, glycogen, gentiobiose, adipic acid, malic acid and trisodium citrate as sole carbon and energy sources, but not glycerol, erythritol, D-arabinose, Larabinose, D-ribose, L-xylose, D-adonitol, methyl $\beta$-Dxylopyranoside, D-galactose, L-sorbose, dulcitol, inositol, 
Table 2. Cellular fatty acid content (\%) of strain $A P 13^{\top}$ and Massilia species

Taxa: 1, strain $\mathrm{AP}^{\mathrm{T}}{ }^{\mathrm{T}}$; 2, M. timonae; 3, M. dura; 4, M. albidiflava; 5, M. plicata; 6, M. lutea. Data for M. dura CCTCC AB $204070^{\mathrm{T}}$, M. albidiflava CCTCC AB $204071^{\mathrm{T}}$, M. plicata CCTCC $\mathrm{AB} 204072^{\mathrm{T}}$ and M. lutea CCTCC $\mathrm{AB} 204073^{\mathrm{T}}$ are from Zhang et al. (2006).

\begin{tabular}{|lcccccc|}
\hline Fatty acid & $\mathbf{1}$ & $\mathbf{2}$ & $\mathbf{3}$ & $\mathbf{4}$ & $\mathbf{5}$ & $\mathbf{6}$ \\
\hline $\mathrm{C}_{10: 0}$ & $0 \cdot 4$ & $0 \cdot 5$ & $0 \cdot 6$ & $1 \cdot 3$ & $1 \cdot 4$ & $0 \cdot 5$ \\
$\mathrm{C}_{10: 0} 3-\mathrm{OH}$ & $4 \cdot 8$ & $4 \cdot 6$ & $8 \cdot 3$ & $9 \cdot 6$ & $10 \cdot 1$ & $4 \cdot 6$ \\
$\mathrm{C}_{12: 0}$ & $4 \cdot 6$ & $4 \cdot 4$ & $5 \cdot 6$ & $6 \cdot 0$ & $7 \cdot 1$ & $2 \cdot 8$ \\
$\mathrm{C}_{12: 0} 2-\mathrm{OH}$ & $1 \cdot 9$ & $1 \cdot 8$ & - & $0 \cdot 7$ & - & - \\
$\mathrm{C}_{14: 0}$ & $0 \cdot 6$ & $\mathrm{Trace}$ & $3 \cdot 2$ & $2 \cdot 8$ & $1 \cdot 6$ & $1 \cdot 9$ \\
$\mathrm{C}_{14: 0} 2-\mathrm{OH}$ & - & - & $3 \cdot 4$ & $3 \cdot 0$ & $6 \cdot 1$ & $2 \cdot 0$ \\
$\mathrm{C}_{15: 0}$ & - & $1 \cdot 1$ & - & - & - & - \\
$\mathrm{C}_{16: 1} \omega 7 c$ & $48 \cdot 3^{*}$ & $49 \cdot 1$ & $46 \cdot 7$ & $46 \cdot 4$ & $36 \cdot 9$ & $54 \cdot 7$ \\
$\mathrm{C}_{16: 0}$ & $36 \cdot 8$ & $27 \cdot 2$ & $25 \cdot 5$ & $22 \cdot 8$ & $25 \cdot 1$ & $22 \cdot 8$ \\
$\mathrm{C}_{18: 1} \omega 7 c$ & $2 \cdot 5$ & $11 \cdot 2$ & $5 \cdot 9$ & $7 \cdot 4$ & $11 \cdot 7$ & $10 \cdot 0$ \\
\hline
\end{tabular}

${ }^{*}$ Fatty acid $\mathrm{C}_{16: 1} \omega 7 c$ is included in summed feature $3\left(\mathrm{C}_{16: 1} \omega 7 c\right.$ and/or iso- $\left.\mathrm{C}_{15: 0} 2-\mathrm{OH}\right)$.

D-mannitol, D-sorbitol, methyl $\alpha$-D-mannopyranoside, methyl $\alpha$-D-glucopyranoside, arbutin, salicin, D-lactose (bovine origin), D-melibiose, sucrose, D-trehalose, inulin, D-melezitose, D-raffinose, xylitol, D-turanose, D-lyxose, D-tagatose, D-fucose, L-fucose, D-arabitol, L-arabitol, potassium gluconate, potassium 2-ketogluconate, potassium 5ketogluconate, L-arabinose, capric acid or phenylacetic acid. Resistant to the following antibiotics: penicillin (10 U per disc), bacitracin (10 U per disc) and cephalothin (30 $\mu \mathrm{g}$ per disc). Sensitive to the following antibiotics ( $\mu$ g per disc): tetracycline (30), rifampicin (30), streptomycin (10), neomycin (10), erythromycin (15), kanamycin (30), vancomycin (30), nalidixic acid (30), novobiocin (30) and chloranphenicol (30). The predominant cellular fatty acids are $\mathrm{C}_{10: 0}(0 \cdot 4 \%), \mathrm{C}_{10: 0} 3-\mathrm{OH}(4 \cdot 8 \%), \mathrm{C}_{12: 0}(4 \cdot 6 \%), \mathrm{C}_{12: 0}$ $2-\mathrm{OH}(1 \cdot 9 \%), \mathrm{C}_{14: 0}(0 \cdot 6 \%), \mathrm{C}_{16: 1} \omega 7 c$ and/or iso- $\mathrm{C}_{15: 0} 2-$ $\mathrm{OH}(48 \cdot 3 \%), \mathrm{C}_{16: 0}(36 \cdot 8 \%)$ and $\mathrm{C}_{18: 1} \omega 7 c(2 \cdot 5 \%)$. The predominant ubiquinone is Q-8. The DNA G $+\mathrm{C}$ content of the type strain is $66 \cdot 0 \mathrm{~mol} \%\left(T_{\mathrm{m}}\right)$.

The type strain, $\quad$ AP $13^{\mathrm{T}} \quad\left(=\mathrm{CECT} \quad 7142^{\mathrm{T}}=\mathrm{CCM}\right.$ $7363^{\mathrm{T}}=$ DSM $18055^{\mathrm{T}}=$ JCM $\left.13879^{\mathrm{T}}\right)$, was isolated from drinking water.

\section{Acknowledgements}

We are grateful to Dr Peter Kämpfer for providing the fatty acid data for the type strain of M. timonae. V. G. was supported by a fellowship from the Spanish Ministerio de Educación y Ciencia. This work was supported by grants from the Quality of Life and Management of Living Resources Programme of the European Commission (QLK3CT-2002-01972), the Spanish Ministerio de Ciencia y Tecnología (BMC2003-01344) and the Junta de Andalucía.

\section{References}

Bauer, A. W., Kirby, W. M. M., Sherris, J. C. \& Turck, M. (1966). Antibiotic susceptibility testing by a standardized single disk method. Am J Clin Pathol 45, 493-496.

Bodour, A. A., Wang, J. M., Brusseau, M. L. \& Maier, R. M. (2003). Temporal change in culturable phenanthrene degraders in response to long-term exposure to phenanthrene in a soil column system. Environ Microbiol 5, 888-895.

Christensen, W. B. (1946). Urea decomposition as a means of differentiating Proteus and paracolon cultures from each other and from Salmonella and Shigella types. J Bacteriol 52, 461-466.

Cowan, S. T. \& Steel, K. J. (1974). Manual for the Identification of Medical Bacteria. Cambridge: Cambridge University Press.

D’Angelo-Picard, C., Faure, D., Penot, I. \& Dessaux, Y. (2005). Diversity of $\mathrm{N}$-acyl homoserine lactone-producing and -degrading bacteria in soil and tobacco rhizosphere. Environ Microbiol 7, 1796-1808.

De Ley, J. \& Tijtgat, R. (1970). Evaluation of membrane filter methods for DNA-DNA hybridization. Antonie van Leeuwenhoek 36, 461-474.

Johnson, J. L. (1994). Similarity analysis of DNAs. In Methods for General and Molecular Bacteriology, pp. 655-681. Edited by P. Gerhardt, R. G. E. Murray, W. A. Wood \& N. R. Krieg. Washington, DC: American Society for Microbiology.

Kämpfer, P. \& Kroppenstedt, R. M. (1996). Numerical analysis of fatty acid patterns of coryneform bacteria and related taxa. Can J Microbiol 42, 989-1005.

Kersters, K., Hinz, K.-H., Hertle, A., Segers, P., Lievens, A., Siegmann, O. \& De Ley, J. (1984). Bordetella avium sp. nov., isolated from the respiratory tracts of turkeys and other birds. Int J Syst Bacteriol 34, 56-70.

Kovács, N. (1956). Identification of Pseudomonas pyocyanea by oxidase reaction. Nature 178, 703-704.

La Scola, B., Birtles, R. J., Mallet, M. N. \& Raoult, D. (1998). Massilia timonae gen. nov., sp. nov., isolated from blood of an immunocompromised patient with cerebellar lesions. J Clin Microbiol 36, 2847-2852.

Lindquist, D., Murrill, D., Burran, W. P., Winans, G., Janda, J. M. \& Probert, W. (2003). Characteristics of Massilia timonae and Massilia timonae-like isolates from human patients, with an emended description of the species. J Clin Microbiol 41, 192-196.

Ludwig, W., Strunk, O., Klugbauer, S., Klugbauer, N., Weizenernegger, M., Neumaier, J., Bachleitner, M. \& Schleifer, K.-H. (1998). Bacterial phylogeny based on comparative sequence analysis. Electrophoresis 19, 554-568.

Ludwig, W., Strunk, O., Westram, R. \& 29 other authors (2004). ARB: a software environment for sequence data. Nucleic Acids Res 32, 1363-1371.

Marmur, J. (1961). A procedure for the isolation of deoxyribonucleic acid from micro-organisms. J Mol Biol 3, 208-218.

Marmur, J. \& Doty, P. (1962). Determination of the base composition of deoxyribonucleic acid from its thermal denaturation temperature. J Mol Biol 5, 109-118.

Mellado, E., Moore, E. R. B., Nieto, J. J. \& Ventosa, A. (1995). Phylogenetic inferences and taxonomic consequences of $16 \mathrm{~S}$ ribosomal DNA sequence comparison of Chromohalobacter marismortui, Volcaniella eurihalina and Deleya salina, and reclassification of $V$. eurihalina as Halomonas eurihalina comb. nov. Int J Syst Bacteriol 45, 712-716.

Miller, L. T. (1982). A single derivatization method for bacterial fatty acid methyl esters including hydroxy acids. J Clin Microbiol 16, 584-586. 
Mormile, M. R., Romine, M. F., García, M. T., Ventosa, A., Bailey, T. J. \& Peyton, B. M. (1999). Halomonas campisalis sp. nov., a denitrifying, moderately haloalkaliphilic bacterium. Syst Appl Microbiol 22, 551-558.

Owen, R. J. \& Hill, L. R. (1979). The estimation of base compositions, base pairing and genome size of bacterial deoxyribonucleic acids. In Identification Methods for Microbiologists, 2nd edn, pp. 217-296. Edited by F. A. Skinner \& D. W. Lovelock. London: Academic Press.

Sierra, G. (1957). A simple method for the detection of lipolytic activity of micro-organisms and some observations on the influence of the contact between cells and fatty substrates. Antonie van Leeuwenhoek 23, 15-22.

Skerman, V. B. D. (1967). A Guide to the Identification of the Genera of Bacteria, 2nd edn. Baltimore: Williams \& Wilkins.
Stackebrandt, E. \& Goebel, B. M. (1994). Taxonomic note: a place for DNA-DNA reassociation and $16 \mathrm{~S}$ rRNA sequence analysis in the present species definition in bacteriology. Int J Syst Bacteriol 44, 846-849.

Ventosa, A., Gutierrez, M. C., Kamekura, M. \& Dyall-Smith, M. L. (1999). Proposal to transfer Halococcus turkmenicus, Halobacterium trapanicum JCM 9743 and strain GSL-11 to Haloterrigena turkmenica gen. nov., comb. nov. Int J Syst Bacteriol 49, 131-136.

Wery, N., Gerike, U., Sharman, A., Chaudhuri, J. B., Hough, D. W. \& Danson, M. J. (2003). Use of a packed-column bioreactor for isolation of diverse protease-producing bacteria from antarctic soil. Appl Environ Microbiol 69, 1457-1464.

Zhang, Y. Q., Li, W. J., Zhang, K. Y., Tian, X. P., Jiang, Y., Xu, L. H., Jiang, C. L. \& La, R. (2006). Massilia dura sp. nov., Massilia albidiflava sp. nov., Massilia plicata sp. nov. and Massilia lutea sp. nov., isolated from soils in China. Int J Syst Evol Microbiol 56, 459-463. 